\title{
Modern Russian Approaches to Correlation of International and Domestic Law
}

\author{
Viatcheslav Gavrilov \\ Professor of Law, Head Chair of International Public and Private Law \\ Far Eastern Federal University (Vladivostok, Russia). S.J.D., Doctor of Law \\ gavrilovfirst@gmail.com; gavrilov.vv@dvfu.ru
}

Doi:10.5901/mjss.2015.v6n5p375

\begin{abstract}
This paper examines basic theoretical conceptions and juridical mechanisms elaborated and used in the Russian legal doctrine and judicial practice for description of correlation and interaction of international and domestic legal norms within legal systems of Russia and some other states. In this respect special attention devotes to theories of transformation and implementation and national normative mechanisms of international law's operation within boundaries of states.
\end{abstract}

Keywords: international law; domestic law, correlation, transformation, implementation, Russia.

\section{Introduction}

New tendencies of the world social development, defined in the late XX - early XXI centuries, raised a number of complex challenges to be solved by science and practice. The main problem is to define substantial characteristics of the future world order as well as to create the necessary mechanisms and procedures of its construction and functioning. The soonest understanding of roots and background of global processes and elaboration of fundamental orientation points for the world development in new historical conditions are on the agenda today.

In this situation international law, becoming one of the main values for the world society, being a necessary instrument for maintenance of the order in the complex system of international relations (Lukashuk, 2001), starts to play more significant role in the process of reorganization of the world social system.

Contemporary international law "has grown from the law of only the so-called "civilized" nations into the law of communication among all States with different social systems and with different backgrounds, meaning developed States, developing states and emerging States" (Marochkin, 2009). In order to fulfill its functions international law reflects cooperation and compromise in the struggle of different religions, ideologies, legal systems, values and strives for synthesis of them (Gavrilov, 2015).

Nowadays "international law still undergoes certain changes and prospects for development at the beginning of a new century and millennium. The incentives for this are the great changes in the social and political picture of the world, the increase (intensification) of coherence and interdependence among States and the globalization process, which is obviously steady and irreversible. Many problems, which were of domestic or regional character, have become universal. The tendency to integration, "disappearance" of frontiers and creation of common political, economic, financial and legal space is obvious" (Marochkin, 2009). As a result, "nowadays, judges in the domestic courts are frequently faced with arguments based on public international law. There is a tendency to "use" - or abuse - international law, or what is said to be international law, to bolster arguments, especially in judicial review cases" (Wood, 2011).

Here we can point out two large groups of factors determining objective necessity of close interaction between international and domestic law in the contemporary world. Phenomena and tendencies of the first group have public, political, and economic character and find their reflection, particularly in internationalization of internal relations, diversification of economy and emergence of human problems, which cannot be solved without close cooperation among the majority of nations.

Globalization exerting dominant influence on these factors led to the fact that nowadays no state can exist without its active and targeted interaction with international legal system. State's welfare depends on how effective such interaction is organized, on how consistently and successfully this state combines in its activity the consideration of its national and international interests.

It is important because from year to year the influence of international legal norms deeply penetrates into the sphere of national relations. As a result, many elements of traditional internal relations are considered today as objects of 
joint regulation, with the participation of national and international legal norms. Steady increase of the international legal factor's gravity in national lawmaking becomes a tendency of development of interaction between international and national law.

All this inevitably affects the essence and development of international law, its characteristics and its significant at universal and national levels. That is why it is very important to know how different states determine the status of international law and tools for its application within their boundaries.

\section{Theories of Correlation of International and Domestic Law}

Russian doctrine of international law highlights two main theories, which have formed in respect of correlation of international and domestic law: monism and dualism. Neither can be called absolutely correct, but each has its own pluses and minuses.

Under the monist theory, international law and domestic law are combined into a single legal system (accordingly, the name of the theory). From its point of view, law by its nature is one and ultimately addressed to individuals and regulates their relations. However, this theory has variations: the primacy (or priority) of international or domestic law.

According to the first (Sir Hersch Lauterpacht (1897-1960), Hans Kelsen (1881-1973) and others), international law has priority over domestic one and in the event of a divergence between them only international law is applied. States retain the competence to regulate matters within the limits of their territory with the assistance of domestic law only insofar as respective questions are not regulated by international law.

The positive features of this version of the monist theory are seen in the fact that its supporters allow the possibility of the operation and application of international law in the sphere of domestic jurisdiction with the sanction of the State. In addition, attention is emphasized on intensifying the role of international law, in particular, the defense of human rights. The supporters of this theory consider that the individual is protected directly by international law, and that absolutization of sovereignty and domestic jurisdiction of states is incompatible with ensuring human rights and freedoms (J. Humphrey, M. Gandji, and Richard Falk). Its defects lie in the excessive overstatement of the role of international law, the proclamation of it to be the highest legal order and the excessive decrease the role of the sovereignty of states (Tuzmukhamedov, 2009, p. 164-165).

The second, opposite, version of the monist theory, which proclaims the priority of domestic law over international, takes its beginning from the views ofGeorg Hegel (1770-1831) on the State as the absolute power on the Earth, which by its will has the right to change norms of both its own and international law (or as the monists called it: "external state" law). The last one represents the totality of the external state law of various countries and is law to the extent to which it forms an integral part of domestic law. Depending on its interests, the state is free to decide whether to comply with international law or not.

Positive here is the fact that the initial role of the wills and interests of states is emphasized in the development of international law. However, the danger exists of the use of similar views to justify arbitrariness in international relations because in accordance with this theory in the event of a divergence of norms of these two legal systems domestic law has priority in application and execution, and not international law. In essence, this leads to denial of international law, to international-legal nihilism.

The dualist theory proceeds from the fact that international and domestic law belong to separate self-governing legal systems independent of one another and having their own specific objects of regulation, subjects, and sources of law. Each is supreme in its own sphere. According to one of the most famous founder and supporter of this theory Heinrich Triepel (1868-1946), international law and domestic law are not only different branches of law, but different legal orders, two neighboring but not intersecting circles.

Same jurists insist on the practically complete closed nature of the international and domestic law systems, one from the other; either of them may not create or change norms of the other, each being a closed system of norms, and there are no legal links between them. Even if with respect to one object norms of both systems operate simultaneously, conflicts do not arise between them as well as international courts apply international law, and national courts, domestic law.

However, representatives of the dualist orientation do not deny and even investigate the interconnection of international and domestic law, the reference of one to the other. International law, they suggest, should constantly turn for assistance to domestic law, without which it may prove to be powerless (Tuzmukhamedov, 2009, p. 165-166).

It is obviously that the dualist theory corresponds to legal reality, to the practice of states more, than does the monist theory, and therein its principal positive feature lies. It emphasizes not only the autonomy and independence of two legal systems, but also the objective inevitability of their mutual influence, the principal role and the responsibility of 
the State in choosing the means and methods of domestic fulfillment of norms of international law and the need to resolve the issue of overcoming conflicts between norms of the two systems when applying international law. The principal defects of the dualist theory lie in the overstatement of the differences and the delimitation of international and domestic law scope, which may be used by a State not to comply with international obligations.

Despite their great theoretical and practical importance, theories of dualism and monism give us just general view of correlation of international and domestic law, but not about their interaction. Meanwhile the last issue plays extraordinary role in the everyday activity of states in respect of international law's application. In the Russian legal doctrine there are two main approaches describing such interaction: 'theory of transformation' and 'theory of implementation'. Each of them based on the dualist theory but they contain quite different understanding of international legal norms' implementation within states.

The main points of transformation theory are following:

1) International and domestic laws are two different legal systems. Therefore, the first one cannot operate directly in the sphere of activity of the second one.

2) For their fulfillment within the State, the norms of international law should be "transformed" into legal norms of domestic law or acquire their force

3) Transformation is typical of all the cases and methods of activity of international law within the State. Act of transformation requires the adoption of special 'transformational' domestic legal act, as, for example, act of ratification of international treaty.

As a result of the transformation process, according to supporters of this theory, the new special domestic law is created, which is similar to original international legal norms in respect of their content, but has already other nature (Gavrilov, 2005, p. 144).

However, the fact that State possesses sovereignty, does not mean, that just domestic law can operate within its boundaries. Any other legal regulators can operate there as well, if certain State allows that. Operating within the State, international legal norms retain their nature and do not turn into norms of domestic law. Consequently, we can speak about interaction and adjustment of international and national norms, but cannot about transform them into each other or join them to each other.

International treaty or custom will never become a part of any domestic law. We can just say that norms of international law can operate inside Russia or other state with their approval as a part of their legal systems, but not as a part of their legislation (Gavrilov, 2005, p. 155). Very interesting, in this regard, is the statement of Prof. Le Zhaojie, who noted: "There is no such thing as 'Chinese international law' any more than there is such a thing as 'Chinese mathematics', there can only be a Chinese theory and practice of international law" (Zhaojie, 2001).

In connection with the above, it is principally important to separate two notions: the law of State as a system of the domestic law (legal rules) of particular country and law applied in the State as a combination of all acts and norms, which operate on the territory of such country. The second notion is wider than the first one, as it includes not only respective domestic law, Russian for example, but also international legal norms applied in our country (Ignatenko, 2009).

Mentioned basic mistake about the possibility of turning international law norms into the norms of domestic law is accompanied in transformation theory by some other defects. For instance, the defenders of this theory insist that all international treaties of State become a part of its legal system after the adoption of ratification's act. This statement does not take into account the presence of different international treaties, which can be oriented on regulation different kind of public relation from a purely interstate (concluded in the area of space exploration, for example) till mainly internal (human right area). Besides, various international treaties contain rules of different degrees of detail. That is why some of them need the adoption of additional domestic laws for their implementation, while others can be directly applied by courts. Finally, not all international treaties require adoption the domestic act of ratification for their entry into force.

Thus, the theory of transformation, in my opinion, gives the wrong idea about the role and place of international law norms in domestic legal systems. The theory of implementation in this respect is much closer to the real practice of the legal regulation of international and domestic relations. The supporters of this theory prove the presence of legal factors of mutual needs of international and domestic law for each other, which exist due to the presence of the general basis in these systems, determining them as legal ones. Furthermore, in many cases, the connection of national and international law as separate legal entities is judicially necessary, especially at the stage of implementation of international legal norms (Zimnenko, 2010).

The main points of this theory can be shortly described as follows:

1) International and domestic laws are two different legal systems. Therefore, the first one can operate in the sphere of activity of second one just with the permission of domestic law.

2) During the process of international legal norms implementation they do not become part of the domestic law, 
but fulfill a regulating function together with it. International norms do not change their nature or form, and in this respect remain their international status.

3) The content of implementation mechanism of international legal norms within the State depends on the type, degree of detail of such norms and on the ultimate goals of international regulation (Gavrilov, 2005, p. 159160).

In the connection with the last statement, the theorists and practitioners determine two main forms of assistance given by domestic to international law. The first one takes place when the main objective of international norms lies in regulating relations outside the State borders (for example, while regulating the issues on political, military, or technological interstate cooperation). As international treaties and customs always oblige the whole country rather than its authorities, the main task of domestic law in this case will be to determine standard basis for functioning of the certain state organs responsible for implementation of its international legal obligations. In other words the domestic legislation in this case gives certain national authorities respective legal rights and obligations.

The other situation takes place when final objective of the international treaties represents a certain level of regulation of relations between the subjects of domestic law of one or several states (for example, while regulating the issues on human rights, international trade or investment contracts' implementation, or copyright protection). The task of domestic law in this case is to determine opportunity and conditions for international legal norms' proper implementation within the country, along with other components of national legal system.

Thus, the role of domestic law in determining of its correlation and interaction with international law is in principle different from the role of the last one. Whereas international law contains only general principles, points of departure, the task of the domestic law of each State is to determine the status of norms of international law within its jurisdiction, the state agencies responsible for the fulfillment thereof, the forms and means of the execution thereof, and the mechanism of implementation as a whole.

\section{National Regulation of International Law's Operation within Domestic Legal Systems}

In the contemporary world there is no unified mechanism of international law norms' implementation within the State. Each country solves this problem independently. States' positions on this issue vary enough: from the priority of all international legal norms over all national laws and even constitutions to the recognition of the possibility of implementing just separate types of international legal norms in special cases and under certain conditions.

At the highest domestic normative-legal level, these questions are regulated by constitutions of the states. Constitutions regulate with varying degrees of detail the external relations of a State and the distribution of respective powers between agencies of State. They variously approach to the interaction of international law with domestic law and have different views on such interaction in respect to international treaties and customs.

Thus, for example, the 1787 United States Constitution proclaims that international treaties are "the supreme Law of the Land" (Art. VI [2]), the Constitution of France of 1958, provides that "international treaties or agreements... shall have force exceeding the force of laws" after the publication of the treaties and their application by other participants (Art. 55). Partly similar conditions can be found in the Constitution of Japan of 1946, which stipulates that the international treaties of Japan will not have any legal force as long as they are not approved by Parliament and published (Art. 73(3), 7 and 98).

Some constitutions adhere to another approach and introduce international treaties, in compliance with determined conditions, directly into the structure of their national legislation. Thus, in accordance with the Constitution of Ukraine of 1996 (Article 9): "international treaties... are a part of national legislation of Ukraine". However, not every international treaty, but only those ratified or otherwise approved by the highest legislative agency, occupy in the hierarchy of Ukrainian legal acts an equal position with national laws.

However, as it have been already argued it is not proper way for the determination of status and place of international law sources within the boundaries of certain State. As we remember, international and domestic laws are really interacting systems. At the same time, it does not mean that one of them can become a part of another because they have different purposes, sources, subjects and forms of operation.

As the cited examples of State constitutions show, the term 'international treaties' often is clarified by means of an indication that not every international treaty may possess priority with respect to a national law. Even more difficulties in this respect there is for determining the status of general (custom) norms of international law in domestic legal systems.

In some constitutions (Germany, Austria, Greece, Portugal) these norms are proclaimed to be an integral part of national law, and their priority is allowed with respect to domestic law. Indeed, certain constitutions stipulate the acquisition of such priority by determined conditions. For example, in accordance with the constitutions of Germany and 
Greece this arises after the establishment of the content of such norms or principles and resolution of the question concerning their affiliation to national law respectively by the Federal Constitutional Court or the Supreme Special Court.

Other constitutions are less open to the penetration of general norms of international law into domestic legal system. Thus, the 1994 Constitution of Belarus provides (Article 8): "The Republic of Belarus shall recognize the priority of generally-recognized principles of international law and shall ensure the conformity of legislation to them". Under the Constitution of Georgia of 1995 (Article 6), "legislation of Georgia shall correspond to generally-recognized principles and norms of international law". The Constitution of Italy of 1947 provides (Article 10): "the legal order of Italy shall be agreed with generally-recognized norms of international law". Some of the formulations cited leave the impression of being declarative; overall, they leave to the State greater opportunities to decide how, and to what extent the conformity of their legislation to customary norms of international law shall be secured.

In contemporary Russian legislation, we also can find many mentions about correlation between international and domestic legal norms. However, the most important are the provisions of the Russian Constitution of 1993. Part 4 of Article 15 of this document stipulates that: "The universally-recognized norms of international law and international treaties of the Russian Federation shall be a component part of its legal system. If an international treaty of the Russian Federation establishes other rules than those envisaged by law, the rules of the international treaty shall be applied."

Establishment of this rule in the Russian Constitution has at least two practical consequences. The first one is that nowadays legal instruments of regulating relations within Russia itself or with the participation of its subjects include not only Russian legislation but international legal norms too. The second one implies that in legal practice of Russian authorities and organizations it is necessary to take into account the principle of priority applying provisions of international treaties in relation to the Russian national legal norms.

More detailed examination of the domestic legislations as well as judicial practice of different states clearly shows that following main questions should be maximally clarified in order to guarantee the implementation of international law's norms within the State:

1) Determination of place of international treaties and customary law in the domestic legal system.

2) Determination of legal conditions of their application (including conditions of provisional application and official publication).

3) Determination of the legal force of international and domestic norms' correlation in the sphere of internal jurisdiction.

4) Creation the rules of definition and practical application of self-executing and non-self-executing norms of international law (Marochkin, 2007).

As practice shows in all these cases choosing the scheme of adjusting international and domestic legal norms depends on the peculiarities of certain country national development; its historical traditions; level of citizens' legal consciousness; work out of national legislation, as well as on the existence of a wide system of authorities ready and able to provide practical implementation of international legal norms. Therefore, only collaborative learning norms of constitution and laws of a particular State, on the one hand, and practice of international law's implementation by State authorities and courts, on the other, will give a clear picture of their real role and place in domestic legal system.

\section{Conclusion}

In conclusion, it should be noted that after adoption of the Russian Federation Constitution in 1993 the problem of interaction between international and national legal norms in the Russian legal system has a distinct practical meaning. In recent years dozens of scientific researches, conferences and meetings of various levels have concerned the content of the Part 4 Article 15 of the Russian Constitution and possible ways of its practical application. Nowadays, not all problems in this field have been finally solved in Russia. Undoubtedly, within the framework of contemporary Russian legal doctrine and judicial practice while elaborating the unitary and distinct idea about the place and role of international treaties and customs in legal system of Russia, a great success was achieved. Annually, these norms increasingly determine internal and external policy of Russia and its legislation. The Russian courts and other law-enforcement authorities in practice actively use them now and, undoubtedly, will effectively use them in future.

\section{References}

Gavrilov, V.V. (2015). Certain Issues of Human Right's International Legal Regulation and Ways of their Solution. Asian Social Science, 11 (21), 28-38. doi:10.5539/ass.v11n21p28.

Gavrilov, V. V. (2005). Notion and Interaction of International and National Legal Systems. Vladivostok: FESU Publishing House. 
Ignatenko, G.V. (2009). Function of International Law in the Domestic Sphere. In G.V. Ignatenko, O.I. Tiunov (Eds.), International Law: Textbook for Universities (pp. 199-204). Moscow: Norma Publishing House.

Lukashuk, I.I. (2001). Globalization and International Law. International Law, Special Issue, 15-32.

Marochkin, S. Yu. (2007). International Law in the Courts of the Russian Federation: Practice of Application. Chinese Journal of International Law, 6, 329-344. doi: 10.1093/chinesejil/jmm013.

Marochkin, S. Yu. (2009). On the Recent Development of International Law: Some Russian Perspectives. Chinese Journal of International Law, 8, 695-714. doi: 10.1093/chinesejil/jmp023.

Tuzmukhamedov, B.R. (2009). Conceptions of Correlation of International Law and National Law. In V.I. Kuznetsov, B.R. Tuzmukhamedov (Eds.), International Law - A Russian Introduction (pp. 163-169). Utrecht: Eleven International Publishing.

Wood, M. (2011). What Is Public International Law? The Need for Clarity about Sources. Asian Journal of International Law, 1, $205-216$. doi: $10.1017 / S 2044251311000014$

Zimnenko, B.L. (2010). International Law and the Legal System of the Russian Federation. General Part: Course of Lectures. Moscow: Statute.

Zhaojie, L. (2001) Legacy of Modern Chinese History: Its Relevance to the Chinese Perspective of the Contemporary International Legal Order. Singapore Journal of International and Comparative Law, 5, 314-326. 